\title{
WHERE WE ARE
}

Main DGGS Office

3354 College Road, Fairbanks, AK 99709

907.451.5010 | dggspubs@alaska.gov

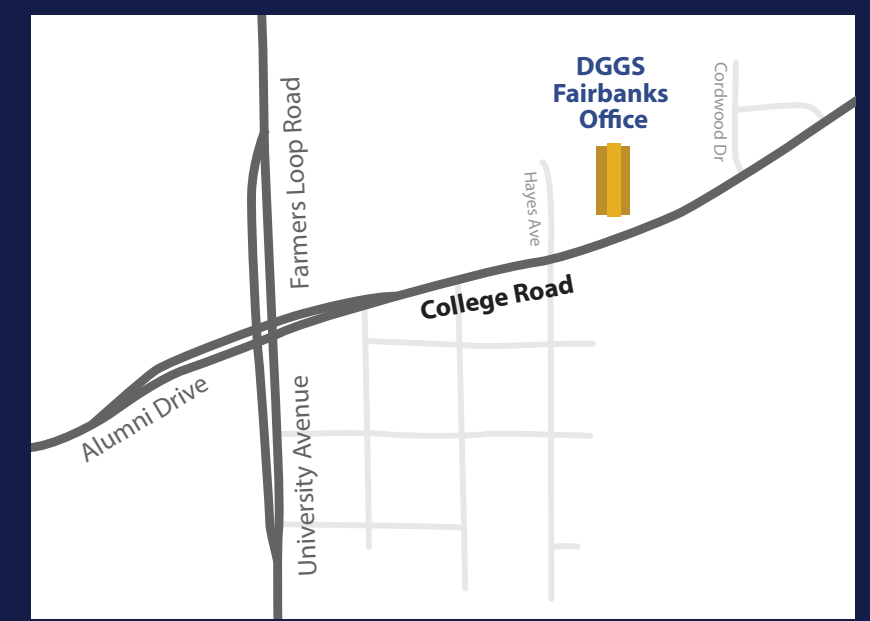

Geologic Materials Center (GMC) 365I Penland Pkwy, Anchorage, AK 99508 907.696.0079

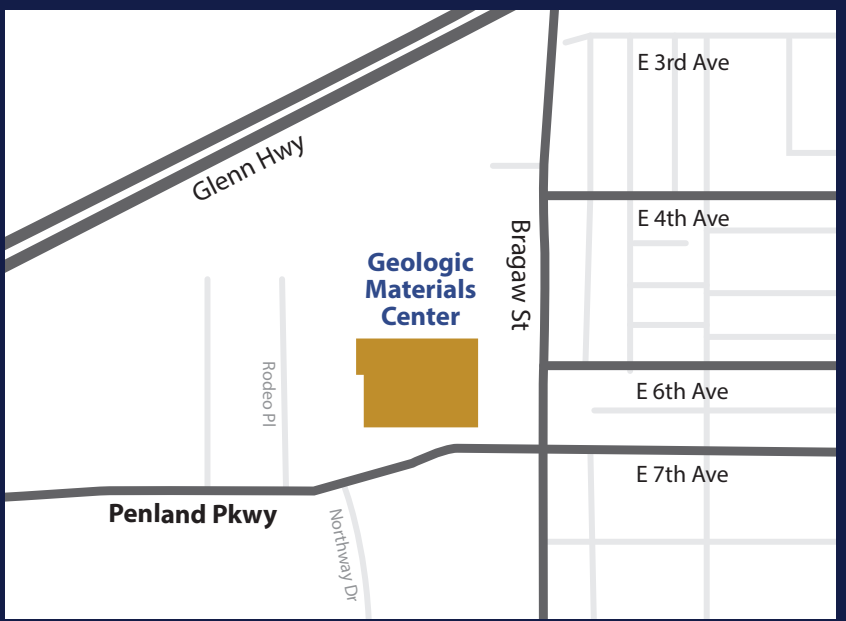

Hours of Operation Monday-Friday | 8:00AM-4:30PM

\section{Our Mission}

Determine the potential of Alaskan land for production of metals, minerals, fuels, and geothermal resources, the locations and supplies of groundwater and construction material, and the potential geologic hazards to buildings, roads, bridges, and other installations and structures.

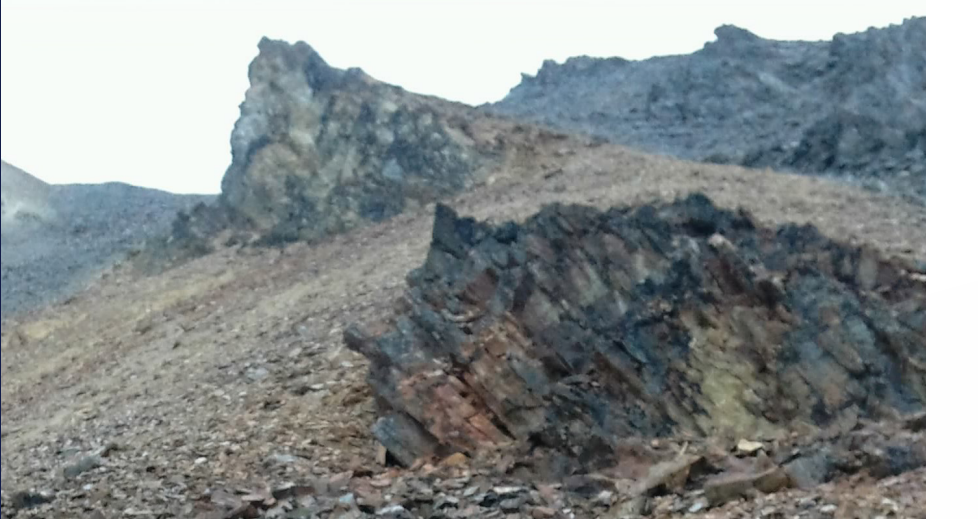

\section{.}
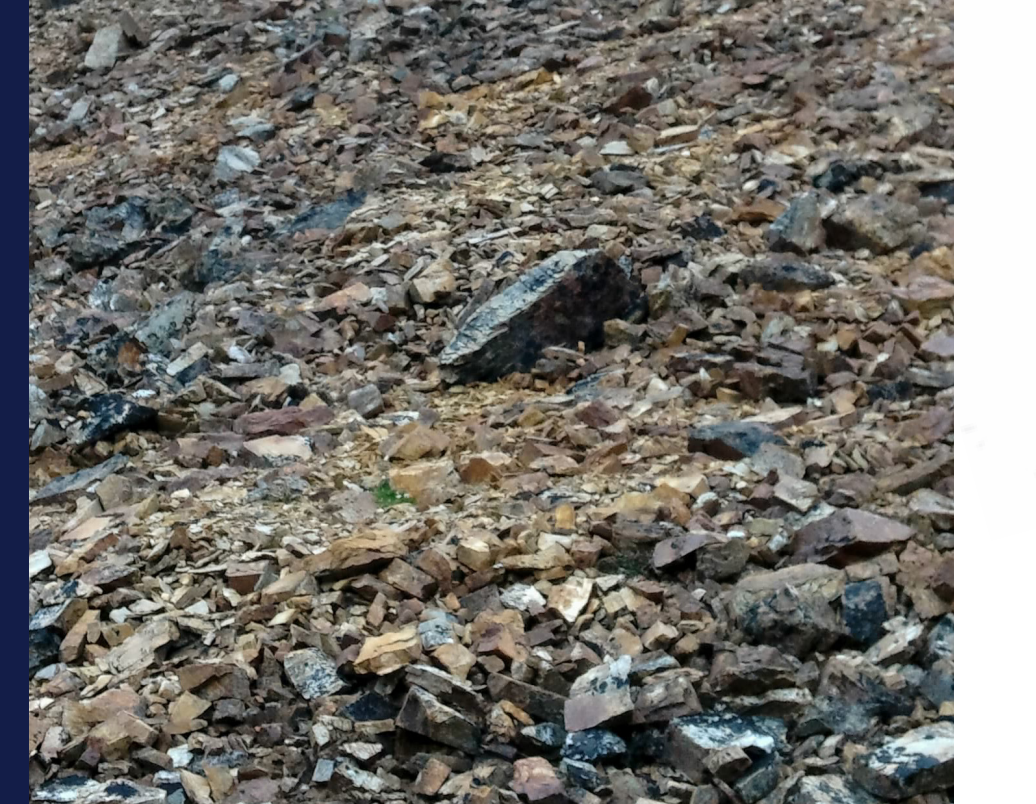

\section{.}

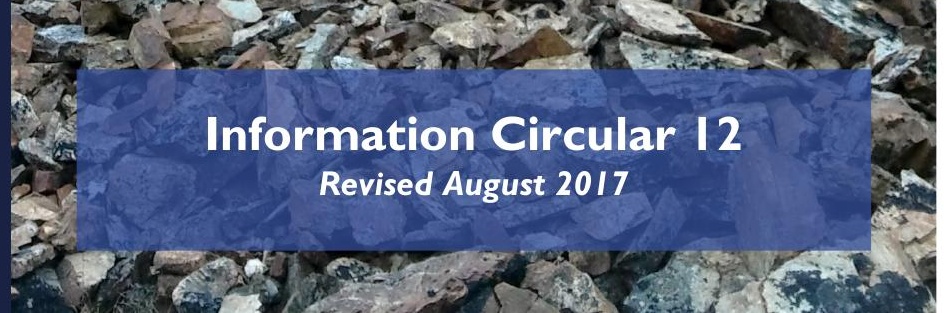

The Alaska Division of Geological \& Geophysical Surveys
3354 College Road

Fairbanks, AK 99709

907.45 I.50 I 0 | dggs.alaska.gov 


\section{WHAT WE DO}

Our research helps Alaska

\section{WHO WE ARE}

Six sections work together to make geologic information available to the public

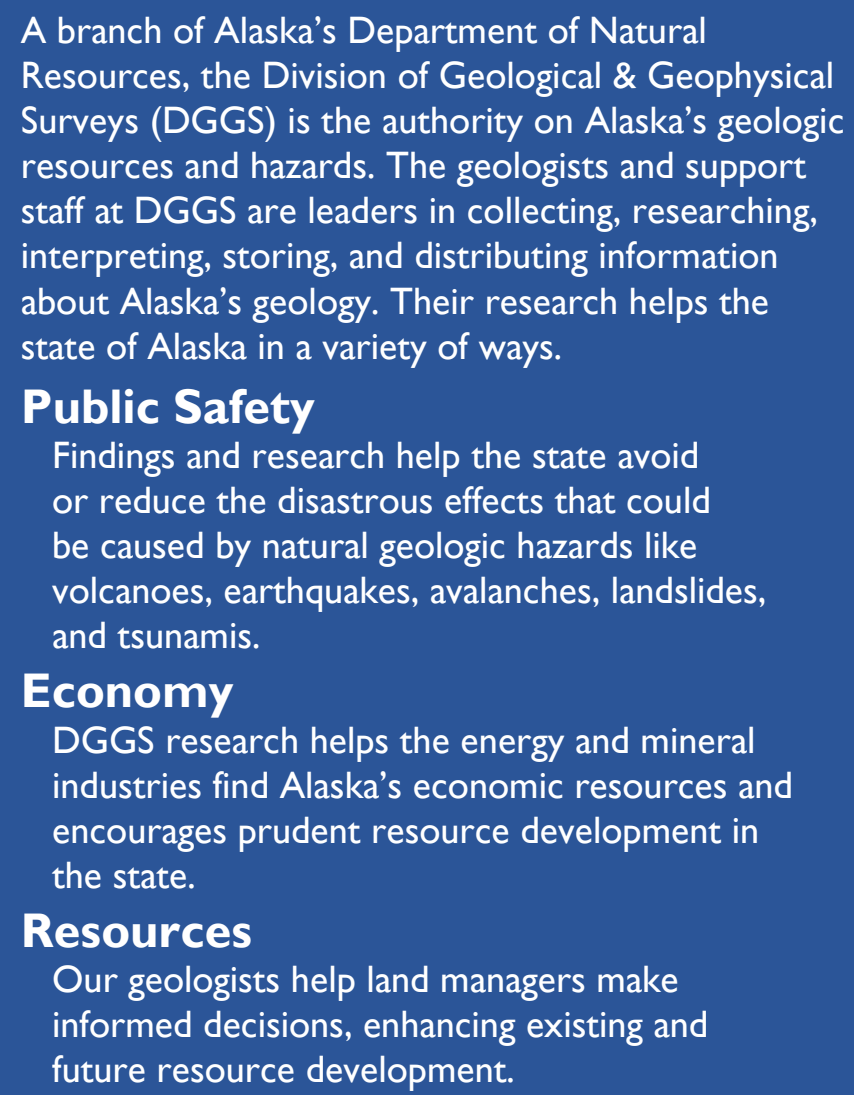

Findings and research help the state avoid or reduce the disastrous effects that could be caused by natural geologic hazards like volcanoes, earthquakes, avalanches, landslides, and tsunamis.

\section{Economy}

DGGS research helps the energy and mineral industries find Alaska's economic resources and encourages prudent resource development in the state.

\section{Resources}

Our geologists help land managers make informed decisions, enhancing existing and future resource development.

\section{Geologic Information Center (GIC)}

All of the reports, maps, and data produced by the geologists at DGGS are published by the GIC. Databases, online interactive maps, and applications are developed and maintained by the $\mathrm{GIC}$ to ensure fast and easy public access to Alaska's vast geologic data.

\section{Geologic Materials Center (GMC)}

Permanent archives of geologic materials and related data are stored at the GMC in Anchorage, Alaska. The oil and gas well cores, mineral boreholes, and geologic samples are valuable to the state, industry, and academia for researching future and current development. Rocks and materials are available in-house to study and sample.

\section{Mineral Resources}

Conducts statewide bedrock geologic mapping, geochemical sampling, geophysical surveying, and mineral resource evaluations. The maps, data, and reports generated by field, office, and laboratory work help promote prudent land management decisions, industry investment, and successful exploration of minerals in Alaska.

\section{Geologic Reference Library and Publications}

DGGS maintains a geologic reference library specializing in geologic information for Alaska. Publications can be viewed or purchased at the DGGS Fairbanks office, or online at dggs.alaska.gov.

\section{Interactive Maps, Tools, and Datasets}

DGGS has developed, and maintains, several interactive maps, tools, and databases, all of which can be accessed at maps.dggs.alaska.gov. They include:

- Tsunami Inundation Maps

- Geologic Map Index of Alaska

- Alaska Shoreline Change Tool
- Geologic Photos of Alaska

- Elevation Datasets

- Historically Active Volcanoes
- Geologic Materials Center Inventory

- Quaternary Faults and Folds

\section{Engineering Geology}

Determines the potential geologic hazards to buildings, roads, bridges, and other infrastructure statewide, as well as the locations and supplies of groundwater and construction materials. The maps and reports they create show the locations of hazards like active faults and the potential for landslides and tsunamis. Their work mitigates risks to public safety, lowers the costs of construction, and promotes informed land-use decisions.

\section{Volcanology}

Monitors and evaluates hazards from 54 historically active volcanoes in the state, and provides timely and accurate warnings of eruptions and unrest. Their field expertise and online data and information distribution aids in efficiently responding to volcanic activity.

\section{Energy Resources}

Produces new geologic information about Alaska's oil, natural gas, coal, and geothermal resources. Geologic reports, maps, and data focus on promising areas in the state for energy resources, which leads to informed industry exploration and discoveries.

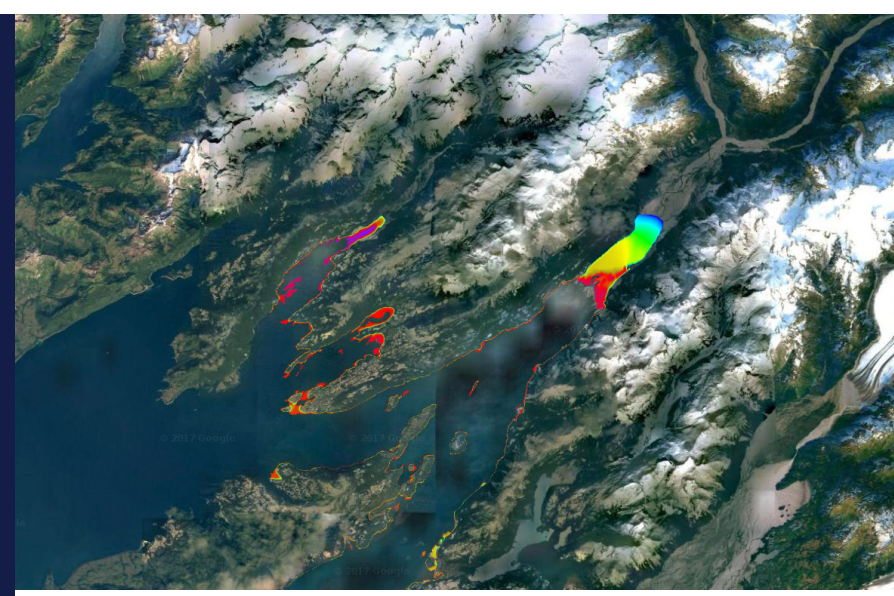

An example of the interactive tsunami inundation map database on the DGGS website. 